Editorial

\title{
Managing Soil Health Towards Sustainable Agriculture
}

\section{M.G.T.S. Amarasekara}

Editor,

Sri Lankan Journal of Agriculture and Ecosystems,

Faculty of Agriculture,

Rajarata University of Sri

Lanka.

\section{Correspondence:} tusita123@gmail.com

https://orcid.org/0000-0002-0221-8850

DOI: http://doi.org/10.4038/sljae.v3i2.77
Macro and microorganisms play a crucial role in improving soil health. Soil organisms decompose complex organic substances and release nutrients Further, they involve in nutrient cycling and transformation process in the soil. Population dynamics of soil organisms depend on many external factors including human activities, climate change, contaminations and soil erosion. Hence, adverse conditions may create a tremendous pressure on soil biota leading to large-scale land degradation and loss of productivity in the long run. The positive effect of soil organic matter (SOM) on soil health is well documented. Soil organic matter serves as a source of nutrients for plant growth, enhances soil aggregation, retains soil moisture, increases infiltration and reduces the risk of soil erosion. Depletion of SOM pool specially in farmlands is a global issue. Therefore, it is essential to manage SOM pool above the threshold level $(1.0-1.5 \%)$ in order to reverse the process of soil degradation. In addition, quality and quantity of SOM pool is one of the crucial factors in order to strengthening resilience and reduce risk of soil degradation. It has been reported that, depletion of Soil Organic Carbon (SOC) pool is grater when essential nutrients are limited in the soil for microbial growth. Thus, application of organic manure with alternative nutrient sources could be a better option to increase SOC pool and soil health.

Keywords: Organic carbon, Soil health, Soil organic matter, Soil organisms

This is an open-access article distributed under the terms of the Creative Commons Attribution 4.0 International License, which permits unrestricted use, distribution and reproduction in any medium provided the original author and source are credited. 
Soil health has been defined as "the capacity of a soil to function as a vital living system within ecosystem and land use boundaries to sustain plant and animal production, maintain or enhance water and air quality, and promote plant and animal health" (Doran and Zeiss 2000). It is a key factor which has to be improved in order to move towards productive and environmentally sound farming systems. Knowing of soil functions such as decomposition, cycling of nutrients and dynamic of microbial population, and their contribution to plant growth is vital to design soil health management practices. Soil health and the soil quality are two terms used interchangeably to indicate the condition of a given soil. However, they may be differentiated in terms of timescale; "soil health" refers to the condition of soil in a short period and "soil quality" over a longer period (Acton and Gregorich 1995).

Decomposition and nutrient cycling processes in the soil are generally governed by soil microbes. Hence, unhealthy soil characteristics such as salinization, acidification, compaction, crusting, water logging conditions may affect adversely on soil biota biodiversity, thus reduce the quality of healthy soils (Lal 2015). The population density of soil microbes depends on many factors including climate, vegetation, soil organic carbon and soil $\mathrm{pH}$
(Orgiazzi et al. 2016). Soil aggregates play a significant role by providing physical environment for soil microorganisms (Drazkiewicz 1994). The assessments of the diversity and abundance of rhizosphere microbes indicated that soil type is an important variable which determine microbial population (Qin et al. 2019). Soil organisms decompose complex organic substances and release nutrients. Mainly bacterial and fungal species involve in this process. In addition, microbes involve many nutrient cycling processes in the soil system. As an example, nitrogen in the soil undergoes many transformations through microbial activities. The process of converting organic nitrogen to plant available ammonium is called mineralization. A specific group of bacteria convert ammonium to nitrate in a process called nitrification. The chemical reduction of nitrate to gaseous nitrogen is another process govern by denitrifying bacteria in the soil specially under anaerobic condition. Nitrogen fixation is the conversion of atmospheric nitrogen to ammonia by both free-living and root-symbiotic organisms and it is one of the most important ways that nitrogen is added to the soils. The importance of macro-organisms for restoring soil quality has also been widely recognized. Conversion of conventional farming to organic farming with mulching, 
cover cropping and adding crop residues can increase the activity of soil macroorganisms. Management practices such as use of inappropriate implements, overuse of agro chemicals and burning of vegetation, result in a reduction of soil biota, both in biomass and diversity, altering the population of the soil organisms. Therefore, identifying the threats and intervention to soil microbial functions is critical for soil health management and agricultural sustainability.

Soil organic matter (SOM) improves soil health. It may vary from 1 to 8 percent in agricultural soils depending on the climate and management practices. Soil organic matter serves as a source of nutrient for plant growth, enhances soil aggregation, retains soil moisture, increases infiltration and reduces the risk of soil erosion (Pimentel et al. 1995). It also provides foods for living organisms in the soil thus improves soil biodiversity. Depletion of SOM pool in the agricultural soils is a global issue which indicates the risk of soil degradation. Guo and Gifford (2002) showed that the conversion of native forests and pastures to croplands reduced soil carbon (C) stocks by 42 and 59\%, respectively. Therefore, it is essential to manage SOM pool above the threshold level (1.0-1.5\%) in order to reverse the process of soil degradation. Soil carbon storage is a vital ecosystem service as it sequesters additional atmospheric $\mathrm{CO}_{2}$ into soil organic carbon (SOC). Fontaine et al. (2004) reported that addition of organic C into the soil accelerates decomposition rate of SOM. They further emphasized that competition among microorganisms for nutrient and energy sources determine the rate of organic $\mathrm{C}$ decomposition. As a result, SOC pool can be depleted when nutrients are limited for the growth of soil microbes. Hence, integrated nutrient management would be a viable strategy to increase SOC in agricultural fields.

Soil degradation leads to decline in soil quality parameters with significant reduction in ecosystem functions. Soil physical degradation generally affects structural attributes including pore geometry and continuity, causing crust formation on the soil surface, lowering water infiltration, increasing surface runoff, and soil erosion (Primental 1995). Soil chemical degradation is reflected by nutrient depletion, acidification, salinization, lowering cation exchange capacity (CEC), increased toxicities, and contamination by hazardous wastes. Soil biological degradation is characterized by loss in soil biodiversity, depletion of the soil organic carbon pool, and increase emission of greenhouse gas from soils into the atmosphere. The combination effect of all three types of degradation processes lead to 
disruption in ecosystem functions such as elemental cycling, water infiltration and purification, altering of the hydrological cycle, and a decline in net biome productivity (Lal 2015).

Soil resilience is the capacity of the soil to recover its quality in response to any natural or anthropogenic alteration. It is a kind of ability of a soil to regain its quality by mitigating adverse external influence (Lal 1997). Managing the quality and quantity of SOC pool is one of the crucial factors in order to strengthen resilience and reduce risk of soil degradation (Syers 1997). However, there is limited literature available on soil health improvement in farming systems on tropical soils. Therefore, any comprehensive study on soil health improvement under tropical condition will be beneficial for bridging existing knowledge gaps.

\section{References}

Acton, D \& Gregorich, L 1995, Understanding soil health. In The Health of Our Soil; Acton, D.F, Gregorich, L J Eds, Towards sustainable agriculture in Canada; Centre or Land and Biological Resources Research Branch, Agriculture and Agri-Food Canada: Ottawa, ON, Canada, p. 138.

Doran, J W \& Zeiss, M R 2000, Soil health and sustainability: Managing the biotic component of soil quality. Applied Soil Ecology 15, 3-11.

Drazkiewicz, M 1994, Distribution of microorganisms in soil aggregates: Effect of aggregate size. Folia Microbiologica. 39, 276-282.

Fontaine, S, Bardoux, G, Abbadie, L \& Mariotti, A 2004, Carbon input to soil may decrease soil carbon content. Ecology letters, 7(4), pp 314- 320.

Guo, L B \& Gifford, R M 2002, Soil Carbon Stocks and Land Use Change: A Meta Analysis. Global Change Biology, 8, 345-360. https://doi.org/10.1046/j.1354-1013.2002 .00486

Gugino, B K, Idowu, O J, Schindelbeck, R R, van Es, H M, Wolfe, D W, Moebius, B N, et al. 2009, Cornell Soil Health Assessment Training Manual, 2nd Edn. Geneva: Cornell University.

Lal, R 1997, Degradation and resilience of soils. Philosophical Transactions of the Royal Society London. B. 352, 997-1010.

Lal, R 2015, Restoring soil quality to mitigate soil degradation. Sustainability, 7, 58755895.

Orgiazzi, A, Bardgett, R D, Barrios, E, BehanPelletier, V, Briones, M J I, Chotte, J L, De Deyn, GB, Eggleton, P, Fierer, N \& Fraser, T 2016, Global Soil Biodiversity Atlas; 
European Commission, Publications Office of the European Union: Luxembourg,; p. 176; Available online: https://esdac.jrc. ec.eur opa.eu/ content/ global- soil-biodiver sitymaps-0 (accessed on 11 october 2021).

Pimentel D, Harvey, C, Resosudormo, P, Sinclair, K, Kurz, D, McNair, M, Crist, S, Shpritz, L, Fitton, L, Saffouri, R, et al 1995 Environmental and economic costs of soil erosion and conservation benefits. Science, $267,1117-1123$.

Qin, K, Dong, X, Jifon, J \& Leskovar, D 2019, Rhizosphere microbial biomass is affected by soil type, organic and water inputs in a bell pepper system. Applied Soil Ecology 138, 80-87.
Syers, J K 1997, Manging soils for long-term productivity. . Philosophical Transactions of the Royal Society London. B, 352, 10111021.

Turbé, A, De Toni, A, Benito, P, Lavelle, P, Lavelle, P, Ruiz, N, Van der Putten, W, Labouze, E \& Mudgal, S. 2010, Soil Biodiversity: Functions, Threats and Tools for Policy Makers. Report for European Commission, DG Environment. Available online: https://ec.europa.eu/ environment/ archives/soil/pdf/biodiversity_ report.pdf (accessed on 8 December 2021). 